\title{
Naturalization, reciprocity and marks of marital violence: male defendants' perceptions
}

Naturalização, reciprocidade e marcas da violência conjugal: percepções de homens processados criminalmente Naturalización, reciprocidad y marcas de la violencia conyugal: percepciones de hombres

procesados criminalmente

\section{Gilvânia Patrícia do Nascimento Paixão', Alvaro Pereira', Nadirlene Pereira Gomes', Anderson Reis de Sousa', Fernanda Matheus Estrela', Ubirajara Ramos Pereira da Silva Filho', Igor Brasil de Araújo' \\ ' Universidade Federal da Bahia, School of Nursing, Postgraduate Program in Nursing. Salvador, Bahia, Brazil.}

How to cite this article:

Paixão GPN, Pereira A, Gomes NP, Souza AR, Estrela FM, Silva Filho URP, et al. Naturalization, reciprocity and marks of conjugal violence: perceptions of criminally prosecuted men.

Rev Bras Enferm [Internet]. 2018;71(1):178-84. DOI: http://dx.doi.org/10.1590/0034-7167-2016-0475

\section{Submission: 09-29-2016 Approval: 02-19-2017}

\section{ABSTRACT}

Objective: to analyze male criminals' perception about marital violence. Method: An exploratory, descriptive, qualitative study undertaken with 23 men who were criminally prosecuted for marital violence. A multimethod data collection was conducted, with individual interview and focal group techniques combined, between May and December 2015. The data collected were initially categorized using the NVIVO ${ }^{\circledR} 11$ software program, and then organized using the Collective Subject Discourse method. Results: the collective discourses reveal that, in the male's perception, conjugal violence is inherent in a marital relationships: it is a private, reciprocal problem that leaves body marks. Conclusion: gender dissymmetry as a social construct is evidenced, signaling the need to create spaces for reflection and re-signification of men and women, from a gender perspective.

Descriptors: Domestic Violence; Intimate Partner Violence; Genre; Masculinities; Public Health.

\section{RESUMO}

Objetivo: analisar a percepção de homens em processo criminal sobre a violência conjugal. Método: Estudo qualitativo exploratório-descritivo, com 23 homens acionados criminalmente por violência conjugal. Os dados foram coletados por multimétodos, tendo como técnicas de coleta a entrevista individual e o grupo focal, entre o período de maio a dezembro de 2015. Os dados coletados foram inicialmente categorizados com auxílio do software NVIVO ${ }^{\circledR} 11$ e, em seguida, organizados de acordo com o método do Discurso do Sujeito Coletivo. Resultados: os discursos coletivos revelam que, na percepção masculina, a violência conjugal é natural na relação conjugal; um problema do âmbito privado; recíproca; e deixa marcas corporais. Conclusão: evidencia-se a dissimetria de gênero como constructo social, sinalizando para a necessidade da criação de espaços de reflexão e ressignificação de homens e mulheres, na perspectiva de gênero.

Descritores: Violência Doméstica; Violência por Parceiro Íntimo; Gênero; Masculinidades; Saúde Pública.

\section{RESUMEN}

Objetivo: analizar la percepción de hombres en proceso criminal sobre la violencia conyugal. Método: Estudio cualitativo exploratorio-descriptivo, con 23 hombres accionados criminalmente por violencia conyugal. Los datos fueron colectados por multimedios, teniendo como técnicas de colecta la entrevista individual y el grupo focal, entre el período de mayo a diciembre de 2015. Los datos colectados fueron inicialmente categorizados con auxilio del software NVIVO ${ }^{\circledR} 11$ y, en seguida, organizados de acuerdo con el método del Discurso del Sujeto Colectivo. Resultados: los discursos colectivos revelan que, en la percepción masculina, la violencia conyugal es natural en la relación conyugal; un problema del ámbito privado; recíproca; y deja marcas corporales. Conclusión: se evidencia la disimetría del género como constructo social, señalando para la necesidad de la creación de espacios de reflexión y resignificación de hombres y mujeres, en la perspectiva de género.

Descriptores: Violencia Doméstica; Violencia por Pareja Íntima; Género; Masculinidades; Salud Pública. 


\section{INTRODUCTION}

Intimate partner violence is the most chronic and costly burden the United States has faced, accounting for the deaths of more than 58,139 women between 1980 and 2008, an average of 2,000 women killed per year ${ }^{(1)}$. In the Brazilian scenario, these data are even more alarming: 13,071 deaths of women between 2009 and 2011, which represents an average of 4,357 deaths per year. The Central-West, Northeast and North Regions had the highest numbers ${ }^{(2)}$.

It is estimated that, in this context, 40,000 Brazilian women seek treatment for problems resulting from violence, representing an annual cost to the Unified Health System of more than five million reais in hospitalizations costs alone ${ }^{(3)}$. Despite the high burden, this value is still underestimated, since the statistics do not include costs with health demands that do not require hospitalization as well as those related to other sectors such as the social, police and legal ${ }^{(4)}$.

Due to the high mortality and costs generated, marital violence has been the object of study in different parts of the world, mainly focusing on women's perception of this form of abuse ${ }^{(1,5)}$. However, including the perceptions of men is essential for proposing strategies to prevent this phenomenon, through spaces that allow for gender reflection among men (and women) ${ }^{(6)}$. This is a perspective supported also in the Maria da Penha Law, a Brazilian public policy to combat violence against women, which highlights the need to include men in recovery programs, in addition to prioritizing the discussion of the gender issue among men involved in criminal actions ${ }^{(6-7)}$.

It is emphasized that gender is considered a constitutive element of social relations, based on the perceived difference between the sexes. Under this perspective, it is a set of cultural characteristics that dictate what roles men and women should play in each society ${ }^{(8)}$. In addition, it ultimately confers a hierarchy between these attributes, giving men a position of authority and ownership regarding women, which makes male power socially legitimized, and marital violence often justified ${ }^{(9)}$.

Considering that the process of deconstruction of conjugal violence requires a theoretical deepening of the phenomenon, it is necessary and relevant to value and investigate the male discourse. In this sense, it is questioned what the perception of male defendants in criminal cases is about marital violence. By taking marital violence as a study object, the research adopts as its objective to analyze their perceptions about marital violence.

\section{METHOD}

\section{Ethical aspects}

The study was approved by the Research Ethics Committee of the Federal University of Bahia. The purpose of the research, the potential risks, study benefits and the right to refuse participation at any time were explained to the participants. The preservation of the recorded images and the confidentiality of the data generated in both stages were also guaranteed, in compliance with the ethical guidelines of the research with human beings, proposed in Resolution 466/2012.

\section{Type of study}

This is a qualitative, exploratory, descriptive study, part of a doctoral dissertation linked to the anchor project 'Re-education of men and women involved in criminal prosecution: a strategy to combat marital violence', developed by the Study and Research Group in Violence and Quality of Life of the UFBA School of Nursing.

\section{Methodological procedures}

\section{Data source and study scenario}

The selection of the study population was intentional, consisting of men who were criminally prosecuted for marital violence. The inclusion criteria were: men who experienced pre-trial detention and were responding without deprivation of liberty for criminal prosecution for marital violence. Men who had lawsuits whose cause was based on violence against the woman, other than the conjugal one, were excluded. The locus was the Jurisdiction of Domestic and Family Violence against Women, from the city of Salvador, Bahia, Brazil. Initial contact was made with the help of a social worker, a jurisdiction employee, and later, via telephone, by the researchers.

The men were invited to participate in a Reflection Group (RG), which was developed during nine meetings, lasting seven months and with a total workload of approximately 50 hours. This quantitative considers the three face-to-face hours of each meeting, added to others spent on 'dispersion activities', delivered at the end of each meeting and held by the participants until the next face-to-face meeting. In the first meeting, they were informed about how the GR worked and about the current research. Those who agreed to continue to participate in the group, in the research, or in both, signed the Free and Informed Consent Term. The meetings of the GR addressed varied topics such as family, domestic and conjugal violence, gender, honor, and peaceful resolution of conflicts.

\section{Data collection, organization and analysis of data}

The data were collected using multimethods, using the techniques of individual interviews and focal groups (performed in the last meeting of the RG). The interviews were individual, in a private room of a municipal public school, also the locus of development of the RG, with an average duration of half an hour each. As a data collection instrument, a semi-structured script was used containing the following guiding question: Tell me what you understand by marital violence. The nine members of the GR and another 14 men participated in this phase, making a total of 23 participants. In order to deepen our findings, a focus group was held in the last meeting of the RG (only with the nine participants), after he completion of all the interviews. For this stage, the same guiding question of the interview was adopted. The research was carried out between May and December 2015, by nurses and nurse-researchers, master's and doctor's candidates, under the supervision of doctors, with extensive experience in this area of knowledge.

The interviews and the focus group were recorded, and their contents transcribed in full. In order to ensure rigor in the study, the transcribed material was fully available to all participants in order to verify if it was reliably expressing what they had said. For 
this strategy, as a support tool - the consolidated criteria for the reporting qualitative research (COREQ) - was adopted. The data collected were initially categorized using the $\mathrm{NVIVO}^{\circledR} 11$ software program, which also enabled the creation of a word cloud, which supports the findings. Next, the data were organized into central ideas and discourses'synthesis, according to the Discourse of the Collective Subject method ${ }^{(10)}$. Participants were identified by the letter $\mathrm{H}$, followed by numbers corresponding to the order of interviews. The results were discussed and interpreted according to the theoretical basis of violence, gender and masculinities.

\section{RESULTS}

The study participants are mostly black, ranging in age from 25 to 62 years old, at basic education level and income between one and two minimum wages. Regarding marital aspects, the relationships ranged from four to 40 years of coexistence, mostly in stable union with children.

The collective discourses allowed us to analyze the male perceptions about conjugal violence, organized into the following categories:

\section{Central idea $\mathbf{1}$ - It is inherent in the conjugal relationship}

Men perceive violence as being part of the conjugal daily life, a reason that arouses resentment and non-understanding of the prison. They also highlight its cyclical and intergenerational aspect, as follows:

\begin{abstract}
Fights occur with every couple. There have been several misunderstandings of this and it has always been like a cloud. The cloud would pass, the problem would pass, and the next day it did not look like it had happened. That kind of thing is normal in every relationship. I remember that my parents fought a lot and my father beat my mother. My hatred is because it was not necessary to put me in a cage because this is natural and every couple faces that. (DSC $\mathrm{H} 3, \mathrm{H} 5, \mathrm{H} 6, \mathrm{H} 7, \mathrm{H} 12, \mathrm{H} 13, \mathrm{H} 15, \mathrm{H} 18, \mathrm{H} 2 \mathrm{O}$ )
\end{abstract}

\section{Central idea 2 - It is a private problem}

Men understand that marital violence is private, and should be resolved between the couple, in the domestic environment, without interference from third parties, including the police, as seen in the following discourse:

She brought the whole event to the public. I tried to pull her into the house so that we both could work it out, but she became altered and we started to quarrel right there, in the street. There were a lot of people watching. When the policeman arrived by car in my house, I said that I did not want to talk, that it was a family problem, just our problem. I thought it was wrong to be arrested, to end up at the police station because of this, because what happens in the family is kept right there. There was no need for it because it was our problem! (DSC $\mathrm{H} 1, \mathrm{H} 5, \mathrm{H} 7, \mathrm{H} 9, \mathrm{H} 10, \mathrm{H} 15, \mathrm{H} 17, \mathrm{H} 18, \mathrm{H} 20, \mathrm{H} 21, \mathrm{H} 22$.)

\section{Central idea 3 - It is reciprocal}

Another perception was that the aggression started initially from the companion and because the man's action was retaliatory, it was not understood as violence. The discourse also reveals a conduct based on the non-acceptance of subjection of man to woman.

She started giving nicknames to me. I did not like it and did the replica of the nicknames. Then she assaulted me, slapped me on the face. I do not think it's right for the man to hit the woman, or for the woman to hit the man. Am I going to be beaten by a woman? No! So I did not think twice: I used two closed-hand slaps and put her things out on the street. I did not hit, I just retaliated! (DSC H1, H3, H4, H8, $\mathrm{H} 11, \mathrm{H} 13, \mathrm{H} 17, \mathrm{H} 18, \mathrm{H} 19)$

\section{Central Idea 4 - It leaves body marks}

Although the understanding about the different forms of expression of conjugal violence - psychological, moral, sexual and physical - is clear, the collective discourse reveals that, in the perception of men in criminal proceedings, physical aggressions with visible marks are highlighted.

There is violence that is more hidden, such as the verbal and the threats, which, despite not including spanking, also hurts. But cursing is normal, it's just offenses, normal discussions between couples. A verbal offense is not important. If it were, everyone would be arrested, because everyone does that. For her to say that I emotionally harass her, she needs to have a medical report that confirms that. Violence also occurs when a person is forced to do [sex] even when he or she does not want to, even if they are married. There is the corporal violence: pushing, hitting, kicking, stabbing and shooting. This can leave bruises, cause bleeding and lead to death. It only becomes violence when the person is beaten, or a weapon or firearm was used. This is violence and cowardice. If I hit a woman, she has to have marks on her body. (DSC H2, H3, $\mathrm{H} 4, \mathrm{H} 5, \mathrm{H} 7, \mathrm{H} 8, \mathrm{H} 10, \mathrm{H} 11, \mathrm{H} 11, \mathrm{H} 12, \mathrm{H} 13, \mathrm{H} 14, \mathrm{H} 15$, $\mathrm{H} 16, \mathrm{H} 17, \mathrm{H} 18, \mathrm{H} 19, \mathrm{H} 20, \mathrm{H} 21, \mathrm{H} 23$ )

These men's perceptions of conjugal violence, unveiled in the illustrated categories, are backed by the "cloud of words", whose words express the essence of the central ideas of the study.

\section{DISCUSSION}

The naturalized male perception of violence in marital relations, present in the masculine discourse, is related to the transgenerational and cyclical characteristics of the phenomenon. Having witnessed violent relationships between their parents since childhood, children tend to naturalize and reproduce this model in their own marital bonds. This finding is corroborated by a study carried out in Romania, which argues that children of couples living in violent relationships are more likely to repeat this behavior in their future relationships ${ }^{(11)}$.

Because it occurs intergenerationally and is apprehended as inherent in the marital relationship, national and international studies have shown that women, as well as men, understand the violent act as love, which favors its perpetuation ${ }^{(12-13)}$. Authors further posit that these aggressive behaviors are used, even if implicitly, as a method of domination, entailing different phases ${ }^{(11)}$

In a study carried out in Brazil, authors describe the cycle of violence as beginning in a phase of accumulation of tension and 
small misunderstandings, of a more psychological and moral character; in turn, there are brief episodes of lack of control, with the occurrence of physical aggression and / or situations considered more serious; finally, there is the phase of reconciliation and promises of change ${ }^{(14)}$. The discourse of men also reveals that the fact that the aggravation is cyclical in the relationship, with alternation of violent episodes and peaceful moments, creates the idea that that moment was fleeting. This cyclical and progressive nature could also be evidenced in a study of 1296 women in Nepal, Asia(15).

It is noticed, therefore, that the intergenerational and cyclical characters incite the naturalization of the violence by the couple, the reason why men do not understand the reason for their prison. A study found that men have difficulty in recognizing the author of a violent act and accepting the reasons that led to their arrest ${ }^{(16)}$, reinforcing the findings of this research. Also corroborating them, other studies indicate that the denial and non-accountability of aggressions by these men are frequent characteristics in the dynamics of conjugal violence ${ }^{(9,17)}$.

This lack of understanding shifts the responsibility of the fact to the companion, as found in this study, when the man justifies that the happened occurred by way of retaliation to an action initiated by the woman. In relationships permeated by violence, the roles of victim and aggressor alternate between partners, but with different means of aggression. The woman often uses profanity and mild physical violence, such as scratches, whereas the man, by having superior physical strength, tends to cause more serious injuries, which reaffirms his superiority ${ }^{(17-18)}$.

Still with respect to the retaliation to the woman, the study points out that it is a way for the man to rescue his masculinity, threatened, since he was beaten by a woman. Corroborating that, authors argue that, when a man is violated by his partner, social questioning about the role of the man in the relationship arises, making him assume an aggressor position to show his superiority ${ }^{(19)}$. This asymmetry is based on relations of power, domination and oppression between the genders, which is related to a patriarchal and phallocentric culture, in which the companion and children are to obey the man, who must be respected ${ }^{(20)}$.

The male's discourse also reveals the understanding that marital problems interest only the couple. This perception is socially shared in popular sayings such as "nobody can do any good between man and wife", thereby clarifying the social understanding that marital problems are intimate, should not be discussed publicly, nor should they be objects of intervention $^{(21)}$. The findings from the study also confirm those found in a survey conducted in the state of Espírito Santo, Brazil, in which men agreed that marital violence should be resolved in the domestic environment. The authors also affirm that this is a conduct that favors male power over the wife, as well as protects him from possible legal-police involvement ${ }^{(22)}$.

In this discourse on the privatization of conjugal violence, it is possible to perceive that when a woman takes the situation outside the walls, the man tries to bring the problem back to the intimate forum. When analyzing data from the Map of Violence 2015 - Homicide of Women in Brazil, it is observed that the home is the privileged place for non-lethal violence, with $71.9 \%$ of records made by women ${ }^{(23)}$. This finding is opposed to the ideal that affective bonds would make the home a safe and propitious place for the whole family to live in peace and harmony ${ }^{(24)}$, showing that marital problems need and must be solved in the public context.

In this respect, one of the main achievements of the feminist movement concerning these abuses was the judicial interference in the private space, which consists of using the police power of the State to intervene in the relations of the private space ${ }^{(21)}$. The Maria da Penha Law is the most expressive mechanism of this juridical conception by criminalizing domestic and family violence against women ${ }^{(21)}$. In addition to criminalization, it has brought a new approach to this type of violence, based on the concept of gender, and typifying the forms of expression of the phenomenon as physical, sexual, psychological, moral and patrimonial ${ }^{(10)}$.

It should be pointed out that the discourse evidenced the masculine perception about various forms of expression of violence listed in the Maria da Penha Law, except for the patrimonial, which may represent a greater difficulty in understanding this form of the offense. The non-comprehension that retention, subtraction, partial and total destruction of personal objects constitutes crimes results in underreporting, and therefore, the percentages of this classification are not significant $^{(25-26)}$. Although in a little exploited way, patrimonial violence has been investigated in national and international studies, evidencing its seriousness ${ }^{(26-28)}$, since it implies difficulties to provide for one's own and family support.

Among the expressions unveiled in this study, the masculine discourse expresses the hidden character of psychological violence, although it recognizes its capacity to leave sequels. Authors found that psychological violence can compromise the self-esteem, well-being and the development of women's psychological and physical health, as well those of the children who witness the offense ${ }^{(29)}$. Another expression recognized was the sexual one, which occurs when the man forces the sexual act without the will of its companion. A study shows that marital rape suggests the male understanding that it is the woman's obligation to satisfy him sexually ${ }^{(30)}$.

Although the discourse reveals the perception about various forms of expression, the greatest severity is evidenced when conditioned to the presence of apparent physical injuries or those confirmed by health professionals. Studies in Brazil and Uganda ${ }^{(17-18,31)}$ corroborate the findings, showing that punches, kicks, burns, strangulation and injuries with a white or firearm are the most perceived forms of violence because they leave visible marks. This fact is in line with current statistics, since international and national studies show ever increasing percentages of physical violence, which is related to its being easily recognizable $\mathrm{e}^{(31-32)}$.

This masculine perception of violence as one that generates visible and serious marks allows us to understand that threats, provocations and insults are sometimes denied as violent behavior because they do not measurable marks. It signals, therefore, toward the non-recognition of the gravity of this phenomenon. Scholars point out that this is an understanding that needs to be deconstructed, which may arise from the reflection of men and women, but above all by the proper education of children so 
that they may act differently in their future relations, breaking the intergenerational cycle of conjugal and family violence ${ }^{(33)}$. In this context, researchers defend the importance of training professionals working in family health teams to prevent marital violence in the community and school environment ${ }^{(34)}$.

In relation to the word cloud, the size of the letters indicates the relevance of the term in the context in which it is displayed. In this manuscript, the image shows that the following words stand out: 'no', 'violence', 'fault', 'she', 'problem', 'natural', 'beat', 'marks', 'woman'. This reinforces the collective perception that the phenomenon is only understood when there are physical marks. Still, the word 'guilt' corroborates the central idea 3 (it is reciprocal), in which the retaliation emphasizes the blame on the other as guilty for initiating the problem.

\section{Limitations of this study}

The limitation of the study relies on the fact that it is applicable only in societies that maintain the same stereotype of gender and marital relations. Because it is a social phenomenon, marital violence can present different perceptions in realities that have different customs from those of the participants of this study. Because it is a public health problem, it is essential to understand the different perceptions that permeate the imaginary of those involved. This understanding is essential for the process of addressing this phenomenon, since it offers subsidies to think about prevention actions and, consequently, to promote the reduction of cases of conjugal violence and its complications for health.

\section{Contributions to the area of nursing, health or public policy}

The preparation of health professionals is deemed as extremely important, in the most diverse spaces. Teams working in primary health care are at a privileged locus, insofar as this is a space focused on the prevention of offenses and diseases, and the promotion of health. In this context, emphasis is placed on the nurses, who are the main managers of these centers and who have a greater link with the community and community health agents, which favors the articulation with neighborhood associations, schools, social welfare reference centers, anonymous alcoholics programs and others, so that the perceptions about violence, as well as the social ideation of the gender roles, can be worked, seeking a respectful solution in the fight against violence.

\section{CONCLUSION}

Collective discourses revealed that, in men understand the phenomenon of conjugal violence as a natural conduct, located in the intimate forum of the couple, and which occurs in a reciprocal manner. While acknowledging the most veiled forms of violence, such as insults, they sometimes consider that, in order to characterize violence, it is necessary to prove it, which is done by means of visible marks, thus highlighting the physical forms.

The study evidenced gender dissymmetry as a social construct, signaling the need to create spaces for reflection and resignification of men and women from a gender perspective. Concerning the transgenerational character, schools are privileged spaces to break this cycle, and should incite actions that promote equitable relationships between girls and boys, based on mutual respect, which enable the deconstruction of the current patriarchal model. Moreover, they should give visibility to the magnitude of each of the forms of expression of violence, favoring the deconstruction of the idea that it is restricted to physical aggression. It is also necessary a type of education that encourages the peaceful resolution of conflicts, as well as an understanding that retaliation is not a defense, but a form of perpetuation of violence, which must be recognized as such.

Furthermore, professionals in the social, judicial, police, educational and healthcare areas must be better prepared to understand this phenomenon of such magnitude and complexity. Therefore, it is essential that the theme be discussed in different scenarios and, in a specialized way, in the core undergraduate curriculum. Moreover, qualification processes are necessary for those who already work in the labor market.

\section{FUNDING}

This manuscript is derived from research funded by the Foundation for Research Support of the State of Bahia (FAPESB), through Public Notice No. 012/2013 - Support for Research on Public Security.

\section{REFERENCES}

1. Dahlstedt JK. Notification and risk management for victims of domestic violence. J Law Gend Soc [Internet]. 2013 [cited 2016 Jul 19];28(1):49. Available from: http://ssrn.com/abstract $=2606512$

2. Garcia LP, Freitas LRS, Silva GDM, Höfelmann DA. Estimativas corrigidas de feminicídios no Brasil, 2009 a 2011. Rev Panam Salud Publica [Internet]. 2015[cited 2016 Jul 19];3737(4545):251-7. Available from: http://www.scielosp.org/pdf/rpsp/v37n4-5/v37n4-5a10.pdf

3. Brasil. Governo Federal. Portal Brasil. Brasileiras lutam pela igualdade de direitos [Internet]. 2012 [cited 2016 Jul 19]. Available from: http://www.brasil.gov.br/cidadania-e-justica/2012/02/brasileiras-lutam-pela-igualdade-de-direitos

4. Juillard C, Smith R, Anaya N, Garcia A, Kahn JG, Dicker RA. Saving lives and saving money: hospital-based violence intervention is cost-effective. J Trauma Acute Care Surg[Internet]. 2015 [cited 2016 Oct 28];78(2):252-7. Available from: http://med.wanfangdata. com.cn/Periodical/Issue id $=101570622 \&$ year $=2015 \&$ issue $=78-2$

5. Cezario ACF, Lourenço LM. Violência conjugal contra o homem: uma análise bibliométrica. Rev Interinstitucional Psicol [Internet]. 2013[cited 2016 Jul 19];6(1):144-56. Available from: http://pepsic.bvsalud.org/pdf/gerais/v6n1/v6n1a11.pdf 
6. Silva ACLG, Coelho EBS, Njaine K. Violência conjugal: as controvérsias no relato dos parceiros íntimos em inquéritos policiais. Cienc Saúde Colet [Internet]. 2014[cited 2016 May 17];19(4):1255-62. Available from: http://www.scielo.br/pdf/csc/v19n4/14138123-csc-19-04-01255.pdf

7. Brasil. Presidência da República. Lei n 11.340, de 7 de Agosto de 2006 [Internet]. 2006[cited 2016 Jul 19]. Available from: http:// www.planalto.gov.br/ccivil_03/_ato2004-2006/2006/lei/l11340.htm

8. Santos G, Buarque C. O que é gênero? Caderno de textos gênero e trabalho. 2009;2(1):23-31

9. Gomes NP, Diniz NMF, Silva Filho CCD, Santos JNB. Enfrentamento da violência doméstica contra a mulher a partir da interdisciplinaridade e intersetorialidade. Rev Enferm UERJ[Internet]. 2015[cited 2016 Jul 19];17(1):121-8.

10. Lefevre F, Lefevre AMC. O discurso do sujeito coletivo: um novo enfoque em pesquisa qualitativa (Desdobramentos). Educs [Internet]. 2003[cited 2016 Jul 19]. Available from: http://www.fsp.usp.br/ flefevre/Discurso_o_que_e.htm

11. Åkerlund N, Sandberg LJ. Children and violence interactions: exploring intimate partner violence and children's experiences of responses. Child Abuse Rev[Internet]. 2016[cited 2016 Nov 01];28(2):219-27. Avaliable from: http://onlinelibrary.wiley.com/ doi/10.1002/car.2438/epdf

12. Cabette ELS, Silva LR. Lei Maria da Penha, violência, medo e amor: da denúncia ao perdão. Rev Jus Navigandi[Internet]. 2013[cited 2016 Jul 19];18(3788). Available from: https://jus.com.br/artigos/25829

13. Sumner SA, Mercy JA, Dahlberg LL, Hillis SD, Klevens J, Houry D. Violence in the united states: status, challenges, and opportunities. JAMA [Internet]. 2015[cited 2016 Jul 11];314(5):478-88. Available from: http://www.ncbi.nlm.nih.gov/pubmed/26241599

14. Thompson ECA. Vitimização e compulsão à repetição: uma reflexão psicanalítica sobre a recorrência da violência[Monografia]. [Internet]. Brasília: Faculdade de Ciências da Educação e Saúde; 2009[cited 2016 Jul 19]. Available from: http://repositorio. uniceub.br/bitstream/123456789/2683/2/20436166.pdf

15. Lamichhane P, Puri M, Tamang J, Dulal B. Women's status and violence against young married women in rural nepal. BMC Womens Health [Internet]. 2011[cited 2016 Jul 11];11(1):19. Available from: http://bmcwomenshealth.biomedcentral.com/ articles/10.1186/1472-6874-11-19

16. Nardi SCS, Benetti SPC. Violência conjugal: estudo das características das relações objetais em homens agressores. Bol Psicol [Internet]. 2012[cited 2016 Jul 19];62(136):53-66. Available from: http://pepsic.bvsalud.org/pdf/bolpsi/v62n136/v62n136a06.pdf

17. Granjeiro I, Costa LF. Gênero, violência conjugal recíproca e interação sistêmica do casal: interpretação da fala de um juiz. Rev Direito Ação [Internet]. 2014 [cited 2016 Jul 19];12(1). Available from: http://dx.doi.org/10.18837/1518-9562/direito.acao. v12n1p15-51

18. Correa RM. Dilemas da Judicialização da violência doméstica: um estudo de caso nos juizados do Distrito Federal. Vivência Rev Antropol [Internet]. 2015 [cited 2016 Jul 19];1(46):31-52. Available from: http://www.periodicos.ufrn.br/vivencia/article/ view/8770

19. Alvim SF, Souza L. Violência conjugal em uma perspectiva relacional: homens e mulheres agredidos/agressores. Rev Psicol Teor Prát. 2005;7(2):171-206

20. Vassal MGP. Aproximação conceitual: gênero, direito, violência contra as mulheres e direitos humanos. In: Capacitação em gênero, acesso à justiça e violência contra as mulheres [Internet]. 2013 [cited 2016 Jul 19]. p. 104-9. Available from: http://www. emerj.tjrj.jus.br/serieaperfeicoamentodemagistrados/paginas/series/14/capacitacaoemgenero_104.pdf

21. Cortizo MC, Goyeneche PL. Judiciarização do privado e violência contra a mulher. Rev Katál Florianóp[Internet]. 2010 [cited 2016 Jul 19];13(1):102-9. Available from: http://www.scielo.br/pdf/rk/v13n1/12

22. Cortez MB, Souza L, Queiróz SS. Violência entre parceiros íntimos: uma análise relacional. Rev Psicol Polít [Internet]. 2010[cited 2016 Jul 19];10(20):227-43. Available from: http://pepsic.bvsalud.org/pdf/rpp/v10n20/v10n20a04.pdf

23. Waiselfisz JJ. Mapa da Violência 2015: homicídio de mulheres no Brasil [Internet]. Brasília; 2015[cited 2016 Jul 19]. Available from: http://www.mapadaviolencia.org.br/pdf2015/MapaViolencia_2015 mulheres.pdf

24. Oliveira MGF, Santos AFPR. E quando um não quer e o outro briga? considerações acerca da judicialização das relações afetivas na cidade de Vila Velha/ES. Estud Sociol[Internet]. 2014[cited 2016 Jul 19];19(36):241-59. Available from: http://seer.fclar.unesp. br/estudos/article/view/5556/5131

25. Pereira RCBR, Loreto MDS, Damiano TKM, Sousa JMM. O fenômeno da violência patrimonial contra a mulher: percepções das vítimas. Oikos Rev Bras Econ Doméstica[Internet]. 2013[cited 2016 Jul 19];24(1):206-35. Available from: http://www.seer.ufv.br/ seer/oikos/index.php/httpwwwseerufvbrseeroikos/article/viewFile/89/156

26. Deere CD, Contreras J, Twyman J. Patrimonial violence: a study of women's property rights in ecuador. Lat Am Perspect [Internet]. 2014 [cited 2016 Jul 19];41(1):143-65. Available from: http://lap.sagepub.com/cgi/doi/10.1177/0094582X13492133

27. Santi LN, Nakano AMS, Lettiere A. Percepção de mulheres em situação de violência sobre o suporte e apoio recebido em seu contexto social. Texto Context Enferm [Internet]. 2010[cited 2016 Jul 19];19(3):417-24. Available from: http://www.scielo.br/pdf/ tce/v19n3/a02v19n3.pdf

28. Acosta DF, Gomes VLO, Barlem ELD. Profile of police reports related to violence against women Acta Paul Enferm [Internet]. 2013 [cited 2016 Jul 19];26(6):547-53. Available from: http://www.scielo.br/pdf/ape/v26n6/en_07.pdf 
29. Fonseca DH, Ribeiro CG, Leal NSB. Violência doméstica contra a mulher: realidades e representações sociais. Psicol Soc [Internet]. 2012 [cited 2016 Jul 19];24(2):307-14. Available from: http://www.scielo.br/pdf/psoc/v24n2/07.pdf

30. Costa AM, Moreira KAP, Henriques ACPT, Marques JF, Fernandes AFC. Violência contra a mulher: caracterização de casos atendidos em um centro estadual de referência. Rev Rede Enferm do Nord [Internet]. 2011 [cited 2016 Jul 11];12(3):627-35. Available from: http://www.redalyc.org/articulo.oa?id = 324027976025

31. Abramsky T, Devries KM, Michau L, Nakuti J, Musuya T, Kiss L, et al. Ecological pathways to prevention: how does the SASA! community mobilisation model work to prevent physical intimate partner violence against women? BMC Public Health [Internet]. 2016[cited 2016 Jul 19];16(1):339. Available from: http://bmcpublichealth.biomedcentral.com/articles/10.1186/ s12889-016-3018-9

32. Brasil. Presidência da República. Secretaria de Políticas para as Mulheres. Relatório Anual Socioeconômico da Mulher [Internet]. Brasília; 2015 [cited 2016 Jul 19]. Available from: http://www.spm.gov.br/central-de-conteudos/publicacoes/publicacoes/2015/ livro-raseam_completo.pdf

33. Jewkes R, Flood M, Lang J, Ricardo C, Eads M, Barker G. From work with men and boys to changes of social norms and reduction of inequities in gender relations: a conceptual shift in prevention of violence against women and girls. Lancet[Internet]. 2015[cited 2016 Jul 19];385(9977):1580-9. Available from: http://www.ncbi.nlm.nih.gov/pubmed/25467578

34. Gomes NP, Erdmann AL, Bettinelli LA, Higashi GDC, Carneiro JB, Diniz NMF. The meaning of professional training for the care of women victims of domestic violence. Esc Anna Nery Rev Enferm [Internet]. 2013 [cited 2016 Jul 19];17(4):683-9. Available from: http://www.gnresearch.org/doi/10.5935/1414-8145.20130012 